\title{
The TEMPI Syndrome - A Novel Multisystem Disease
}

\section{Citation}

Sykes, David B., Wilfried Schroyens, and Casey O'Connell. 2011. “The TEMPI Syndrome - A Novel Multisystem Disease." New England Journal of Medicine 365(5)(August 4): 475-477. doi:10.1056/nejmc1106670.

\section{Published Version}

doi:10.1056/NEJMc1106670

\section{Permanent link}

http://nrs.harvard.edu/urn-3:HUL.InstRepos:37140304

\section{Terms of Use}

This article was downloaded from Harvard University's DASH repository, and is made available under the terms and conditions applicable to Other Posted Material, as set forth at http:// nrs.harvard.edu/urn-3:HUL.InstRepos:dash.current.terms-of-use\#LAA

\section{Share Your Story}

The Harvard community has made this article openly available.

Please share how this access benefits you. Submit a story.

Accessibility 
patients who underwent a baseline bone marrow evaluation at the time of diagnosis; in 21 of these patients (3.2\%), the percentage of bone marrow plasma cells was at least $60 \%$. The median time to progression to symptomatic myeloma was significantly shorter among the patients with $60 \%$ or more bone marrow involvement, as compared with those having less than $60 \%$ involvement $(\mathrm{P}<0.001)$ (Fig. 1). Progression to myeloma occurred within 2 years of the diagnosis in $95 \%$ of the patients with $60 \%$ or more bone marrow plasma cells, with a median time to progression of 7 months (95\% CI, 1.0 to 12.9). We conclude that the natural history of SMM is based almost exclusively on data from patients in whom the number of bone marrow plasma cells is less than $60 \%$. In patients without end-organ damage at diagnosis but with $60 \%$ or greater bone marrow involvement, the clinical course is characterized by progression to symptomatic myeloma within 2 years. Such patients should be considered to have myeloma that requires therapy at the time of diagnosis.

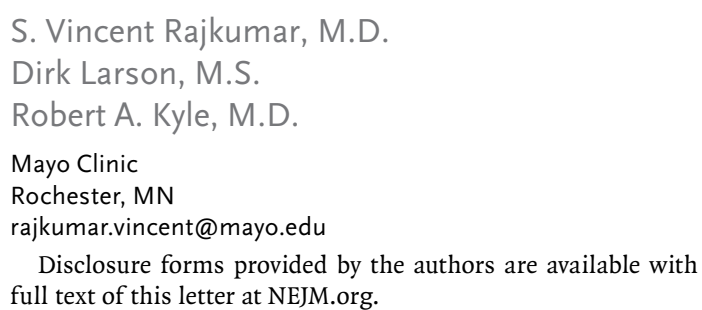

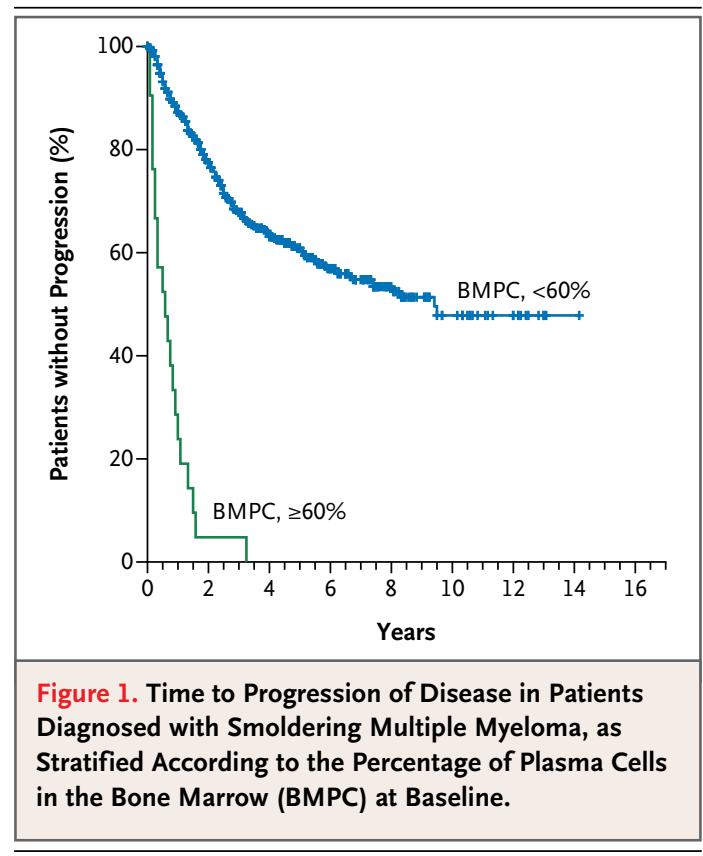

1. Kyle RA, Remstein ED, Therneau TM, et al. Clinical course and prognosis of smoldering (asymptomatic) multiple myeloma. N Engl J Med 2007;356:2582-90.

2. The International Myeloma Working Group. Criteria for the classification of monoclonal gammopathies, multiple myeloma and related disorders: a report of the International Myeloma Working Group. Br J Haematol 2003;121:749-57.

3. Kyle RA, Rajkumar SV. Criteria for diagnosis, staging, risk stratification and response assessment of multiple myeloma. Leukemia 2009;23:3-9.

\section{The TEMPI Syndrome - A Novel Multisystem Disease}

TO THE EDITOR: The description of a man with erythrocytosis and perinephric fluid collections recently appeared in the Case Records of the Massachusetts General Hospital ${ }^{1}$ (Patient 1 in Table 1), and the authors of that article appealed to readers to share similar cases. Two additional patients were identified (Patients 2 and 3), and a review of the literature identified three more patients with similar findings ${ }^{2-4}$ (Patients 4, 5, and 6). These six patients shared five characteristics - telangiectasias, elevated erythropoietin level and erythrocytosis, monoclonal gammopathy, perinephricfluid collections, and intrapulmonary shunting - defining a syndrome that we have termed the TEMPI syndrome.

The four men and two women presented between the ages of 35 and 56 years. In the three patients for whom we have longitudinal followup, the symptoms have been slowly and steadily progressive. Telangiectasias developed over the face, trunk, and arms. Increases in serum erythropoietin levels, which eventually reached values exceeding $5000 \mathrm{mU}$ per milliliter, preceded the intrapulmonary shunting and the development of hypoxemia. Sampling of the perinephric fluid revealed a clear, aseptic, serous fluid having low levels of protein, few leukocytes, and no cholesterol or triglycerides. In the four patients tested, serum protein electrophoresis revealed an IgG monoclonal gammopathy of approximately $0.7 \mathrm{~g}$ per deciliter (with an associated kappa light chain in all three patients tested). Bone marrow biopsies revealed less than $10 \%$ plasma cells, consistent with a monoclonal gammopathy 


\begin{tabular}{|c|c|c|c|c|c|c|}
\hline Characteristic & Patient 1 & Patient 2 & Patient 3 & Patient 4 & Patient 5 & Patient 6 \\
\hline \multicolumn{7}{|l|}{ Demographic } \\
\hline Age (yr) & 42 & 36 & 39 & 35 & 56 & 36 \\
\hline Sex & Male & Female & Female & Male & Male & Male \\
\hline Year of presentation & 2001 & 2005 & 1991 & 1978 & 1970 & 2002 \\
\hline Geographic location & Memphis, TN & $\begin{array}{l}\text { Antwerp, } \\
\text { Belgium }\end{array}$ & Los Angeles & $\begin{array}{l}\text { Manchester, } \\
\text { U.K. }\end{array}$ & Seattle & Indianapolis \\
\hline Race or ethnic group & White & Belgian & Indian & White & Finnish & Mexican \\
\hline \multicolumn{7}{|l|}{ TEMPI syndrome } \\
\hline $\begin{array}{l}\text { Telangiectasias, most prominent over } \\
\text { the face, trunk, arms, and hands }\end{array}$ & Yes & Yes & Yes & NR & Yes & NR \\
\hline Erythrocytosis & Yes & Yes & Yes & Yes & Yes & Yes \\
\hline Hematocrit at presentation (\%) & 58 & 64 & 58 & 62 & 66 & 73 \\
\hline \multicolumn{7}{|l|}{ Erythropoietin (mU/ml) } \\
\hline First measurement & 16 & 50 & 600 & NR & Increased & 38 \\
\hline Highest value & $>5000$ & $>5000$ & $>5000$ & $>500$ & Increased & NR \\
\hline Monoclonal gammopathy & IgG kappa & IgG kappa & IgG kappa & NR & $\lg G$ & NR \\
\hline MGUS & Yes & Yes & Yes & NR & NR & NR \\
\hline $\begin{array}{l}\text { Perinephric fluid between the kidney and } \\
\text { the renal capsule, without paren- } \\
\text { chymal renal cysts }\end{array}$ & Yes & Yes & Yes & Yes & NR & Yes \\
\hline Requiring surgical marsupialization & Yes & No & Yes & Yes & No & Yes \\
\hline Intrapulmonary shunting, microscopic & Yes & Yes & Yes & NR & Yes & NR \\
\hline Hypoxemia & Yes & Yes & Yes & NR & Yes & Yes \\
\hline \multicolumn{7}{|l|}{ Other } \\
\hline Venous thrombosist & Yes & Yes & Yes & NR & NR & NR \\
\hline Spontaneous intracranial hemorrhage & No & Yes & Yes & NR & NR & NR \\
\hline
\end{tabular}

* Race or ethnic group was reported by the investigators. MGUS denotes monoclonal gammopathy of unknown clinical significance, and NR not reported.

$\uparrow$ Thrombosis involved the internal jugular vein in Patient 1 , the cerebral venous sinus in Patients 2 and 3 , and the common femoral vein in Patient 3.

of unknown significance. Three patients suffered spontaneous venous thromboses, and two have had spontaneous intracranial hemorrhages without identifiable arteriovenous malformations.

Despite extensive imaging and testing, the pathophysiology underlying this syndrome remains unclear. The presence of an IgG kappa paraprotein in all three patients tested may suggest a pathogenic role of the paraprotein.

Trials of immunomodulatory agents (thalidomide in Patient 2), anti-vascular epithelial growth factor therapy (bevacizumab in Patient 2), and immunosuppressive agents (sirolimus in Patient 1) were not effective. Treatment of Patient 2 with the proteasome inhibitor bortezomib (8 cycles,
4 doses of $1.3 \mathrm{mg}$ per square meter of bodysurface area per cycle) resulted in the disappearance of telangiectasias, normalization of the serum erythropoietin level, eradication of the monoclonal gammopathy, resolution of the perinephric-fluid collection, and a decrease in the intrapulmonary shunting. This dramatic response supports the hypothesis that the IgG kappa paraprotein is involved in the pathophysiology of TEMPI syndrome.

Our patients underwent extensive testing to evaluate their undiagnosed medical condition, and we are grateful to them and to the physicians who participated directly and indirectly in their care. We suspect that other, similar patients exist, and 
we would welcome any reader insights, with the goal of uncovering the physiological basis of this new disease.

David B. Sykes, M.D., Ph.D.

Massachusetts General Hospital

Boston, MA

dbsykes@partners.org

Wilfried Schroyens, M.D., Ph.D.

Antwerp University Hospital

Antwerp, Belgium

Casey O'Connell, M.D.

University of Southern California

Los Angeles, CA

Disclosure forms provided by the authors are available with the full text of this letter at NEJM.org

1. Case Records of the Massachusetts General Hospital (Case 23-2010). N Engl J Med 2010;363:463-75.

2. Burton IE, Sambrook P, McWilliam LJ. Secondary polycythaemia associated with bilateral renal lymphocoeles. Postgrad Med J 1994;70:515-7.

3. Olerud JE, Robertson HT, Hossack KF, et al. A patient with polycythemia. West J Med 1981;135:375-82.

4. Shaheen M, Hilgarth KA, Hawes D, Badve S, Antony AC. A Mexican man with "too much blood." Lancet 2003;362:806.

Correspondence Copyright @ 2011 Massachusetts Medical Society.

\section{INSTRUCTIONS FOR LETTERS TO THE EDITOR}

Letters to the Editor are considered for publication, subject to editing and abridgment, provided they do not contain material that has been submitted or published elsewhere. Please note the following:

- Letters in reference to a Journal article must not exceed 175 words (excluding references) and must be received within 3 weeks after publication of the article.

- Letters not related to a Journal article must not exceed 400 words.

- A letter can have no more than five references and one figure or table.

- A letter can be signed by no more than three authors.

- Financial associations or other possible conflicts of interest must be disclosed. Disclosures will be published with the letters. (For authors of Journal articles who are responding to letters, we will only publish new relevant relationships that have developed since publication of the article.)

- Include your full mailing address, telephone number, fax number, and e-mail address with your letter.

- All letters must be submitted at authors.NEJM.org.

Letters that do not adhere to these instructions will not be considered. We will notify you when we have made a decision about possible publication. Letters regarding a recent Journal article may be shared with the authors of that article. We are unable to provide prepublication proofs. Submission of a letter constitutes permission for the Massachusetts Medical Society, its licensees, and its assignees to use it in the Journal's various print and electronic publications and in collections, revisions, and any other form or medium.

\section{CORRECTIONS}

Early-Childhood Membranous Nephropathy Due to Cationic Bovine Serum Albumin (June 2, 2011;22:2101-10). The affiliations (page 2101) should have read, "From INSERM, Unite Mixte de Recherche Scientifique 702, Université Pierre et Marie Curie . . ." rather than, "From Université Pierre et Marie Curie . . .." We regret the error. The article is correct at NEJM.org.

Cardiac Arrest in Public versus at Home (April 28, 2011;364: 1674-6). In the third letter to the Editor (page 1675), beginning "Many questions . . . ", the second sentence should have read, "The widespread awareness and acceptance of CPR are the product of national ignorance of its downside, majority prevalence of permanent brain damage outcomes among the $8.4 \%$ of cardiac arrest victims who do survive CPR (about 25,000 each year)," rather than ". . . national ignorance of CPR's downside: the broad range of outcomes of permanent brain damage among $8.4 \%$ of the 25,000 who survive each year." We regret the error. The article is correct at NEJM.org.

\section{NOTICES}

Notices submitted for publication should contain a mailing address and telephone number of a contact person or department. We regret that we are unable to publish all notices received. Notices also appear on the Journal's Web site (NEJM.org/medical-conference). The listings can be viewed in their entirety or filtered by specialty, location, or month.

\section{TH INTERNATIONAL MEETING ON INTENSIVE CARDIAC CARE}

The meeting will be held in Tel Aviv, Israel, Oct. 31 and Nov. 1.

Contact the Secretariat, 7th International Meeting on Intensive Cardiac Care, P.O. Box 574, Jerusalem 91004, Israel; or call (972) 2 6520574; or fax (972) 2 6520558; or see http://www .isas.co.il/cardiac-care2001; or e-mail conventions@isas.co.il.

\section{ANNUAL PROBIOTIC SYMPOSIUM}

The symposium, entitled "Putting Probiotics into Practice: Applications for Health," will be held in Alexandria, VA, Sept. 23 and 24. Deadline for early registration is Aug. 21.

Contact the Annual Probiotic Symposium, 10439 Double R Blvd., Reno, NV 89521; or call (866) 216-6127; or e-mail info@probioticsymposium.com; or see http://www .probioticsymposium.com.

\section{LASER \& AESTHETIC SKIN THERAPY: WHAT'S THE TRUTH?}

The course will be offered in Boston, Oct. 14-16. It is jointly sponsored by Harvard Medical School Department of Continuing Education, Massachusetts General Hospital Department of Dermatology, and the Wellman Center for Photomedicine.

Contact Harvard Medical School Department of Continuing Education, P.O. Box 825, Boston, MA 02117-0825; or call (617) 384-8600; or e-mail hms-cme@hms.harvard.edu; or see http:/l www.cme.hms.harvard.edu/courses/laser. 